\title{
PENGARUH PENERAPAN SUPLEMEN BUKU SISWA BERBASIS SCIENTIFIC APPROACH TERHADAP HASIL BELAJAR DAN SIKAP ILMIAH SISWA
}

\author{
Deni Kurniawan, Eko Suyanto, I Dewa Putu Nyeneng \\ Program Studi Pendidikan Fisika, Universitas Lampung \\ Email: denikurniawan2006@gmail.com
}

Diterima: 5 Agustus 2019 Disetujui: 13 Januari 2020

\begin{abstract}
Abstrak
Penelitian ini bertujuan untuk mendeskripsikan pengaruh penerapan suplemen buku siswa berbasis scientific approach terhadap hasil belajar dan sikap ilmiah pada materi dinamika gerak. Sampel penelitian ini adalah siswa kelas X IPA 1 dan siswa kelas X IPA 2 SMAN 15 Bandarlampung. Penelitian ini menggunakan tipe penelitian pretest-posttest control group design. Rata-rata $\mathrm{N}$-gain hasil belajar pada kelas eksperimen 0,75 dan kelas kontrol 0,62. Rata-rata $N$-gain sikap ilmiah pada kelas eksperimen 0,32 dan kelas kontrol 0,23 . Nilai effect size hasil belajar ialah 0,88 dan sikap ilmiah ialah 1,34 . Berdasarkan nilai rata-rata $N$-gain siswa kelas eksperimen yang lebih tiggi dari kelas kontrol dan effect size yang diperoleh, maka suplemen buku siswa berbasis scientific approach d apat digunakan untuk membantu meningkatkan hasil belajar sikap ilmiah siswa.
\end{abstract}

Kata Kunci: Suplemen Buku Siswa, Scientific Approach, Hasil Belajar, Sikap Ilmiah.

\begin{abstract}
This study aims to describe the effect of the application of a scientific book supplement based on a scientific approach to learning outcomes and scientific attitudes on the material dynamics of motion. The samples of this study were students of Class X Science 1 and Class X Science 2 of SMAN 15 Bandarlampung. This study uses a pretest-posttest control group design research typeThe average $N$-gain learning outcomes in the experimental class were 0.75 and the control class was 0.62 . The average $N$-gain scientific attitude in the experimental class is 0.32 and the control class is 0.23. The value of the effect size of learning outcomes is 0.88 and scientific attitude is 1.34. Based on the average $N$-gain value of the experimental class students who were higher than the control class and the effect size obtained, the student book supplement based on scientific approach and can be used to help improve student learning outcomes in scientific attitudes.

Keywords: Student Book Supplements, Scientific Approach, Learning Outcomes, Scientific Attitudes.
\end{abstract}


Kurniawan., Suyanto., Nyeneng. - Pengaruh Penerapan Suplemen Buku...

\section{PENDAHULUAN}

Pelaksanaan program pendidikan tentunya memerlukan peran guru dan media dalam proses pembelajaran. Penggunaan media dalam pembelajaran dimaksudkan untuk mengatasi berbagai hambatan dalam proses pembelajaran serta mampu membantu keefektifan proses pembelajaran dan penyampaian pesan dan isi pelajaran, sehingga tujuan pembelajaran dapat tercapai dengan maksimal.

Salah satu komponen penting yang menunjang pelaksanaan proses pembelajaran guna meningkatkan kemandirian belajar siswa adalah sumber belajar yang biasanya berupa buku teks pelajaran. Buku teks pelajaran merupakan alat pelajaran yang paling populer dan banyak digunakan di tengahpenggunaan alat pelajaran lainnya, di mana alat cetak telah memasuki abad modern yang diharapkan mampu memotivasi siswa membaca dan memahami materi pembelajaran secara mandiri (Supardi, 2014).

Penggunaan buku teks pelajaran yang ada selama ini juga memiliki kelamhan. Sekitar $70 \%$ buku teks yang digunakan dalam kegiatan pembelajaran fisika berada dalam kategori cukup dan buruk, sehingga sulit untuk dijadikan media dan sarana dalam membangun pengetahuan mereka (Bancong \& Song, 2018). Selain itu, sebagai bahan ajar utama dalam pembelajaran menjadi lemah tanpa adanya bahan ajar suplemen menjadikan proses pembelajaran di sekolah menjadi terasa hambar dan kurang menarik (Supardi, 2014).

Buku siswa atau buku penunjang pembelajaran sebagai komponen penting dalam dan sangat besar manfaatnya di antaranya; memberi pengalaman belajar secara langsung dan konkret kepada siswa, memberi informasi yang akurat dan terbaru, dan memberi motivasi yang positif apabila diatur dan direncanakan pemanfaatannya secara tepat. Suplemen buku siswa juga dapat digunakan sebagai buku penunjang dan pelengkap dari buku teks pelajaran yang memuat komponen yang tak terdapat pada buku teks pelajaran.

Berdasarkan hasil wawancara dan observasi di SMAN 15 
Bandarlampung, siswa mengaku nilai ulangan formatif siswa tahun kesulitan memahami materi fisika pelajaran 2017/2018 pada materi terlebih lagi dalam menjawab soal- dinamika gerak, hanya $48 \%$ siswa soal fisika. Terkait dengan yang memperoleh nilai di atas KKM, kemampuan menjawab pertanyaan dasar mengenai fisika, sebanyak $40 \%$ siswa yang belum paham dan tidak dapat menjawab pertanyaan tersebut. Sebanyak $71 \%$ siswa mengeluh mengenai manfaat dari mempelajari fisika. Mereka menganggap bahwa fisika adalah pelajaran yang abstrak dan mereka tidak tahu penerapan ilmu fisika dalam kehidupan sehari-hari. Ketidaktahuan siswa dalam penerapan konsep fisika berdampak pada sikap ilmiah siswa yang rendah sebab sikap ilmiah memiliki perhatian besar terhadap ilmu pengetahuan.

Sikap ilmiah merupakan sikap yang harus ada pada diri seorang akademisi ketika menghadapi persoalan-persoalan ilmiah. Cara mengajar guru dianggap tidak menyenangkan karena cenderung menggunakan model konvensional sehingga siswa terkadang merasa bosan. Permasalahan-permasalahan yang muncul di lapangan tersebut ternyata mempengaruhi hasil belajar siswa. Hal itu terbukti dari perolehan akibatnya banyak siswa yang harus remedial.Pembelajaran yang selama ini berlangsung, guru menggunakan buku teks yang mendominasi tanpa ada penjelasan lanjut sehingga pembelajaran menjadi sulit dimengerti dan berpengaruh terhadap rendahnya hasil belajar dansikap ilmiah siswa.

Persoalan peningkatan hasil belajar dan sikap ilmiah dapat diatasi dengan penggunaan pendekatan pembelajaran. Agar hasil belajar dan sikap ilmiah tercapai secara optimal, perlu digunakan suatu pendekatan pembelajaran yang sesuai dengan perubahan paradigma dari mengajarkan siswa menjadi membelajarkan siswa, serta menekankan pada proses belajar siswa. Pendekatan pembelajaran yang sesuai dengan hal tersebut ialah pendekatan saintifik (scientific approach). Hal ini dikarenakan scientific approach memiliki krelasi positif dalam pembelajaran siswa (Ratnasari, 2017). 
Kurniawan., Suyanto., Nyeneng. - Pengaruh Penerapan Suplemen Buku...

\begin{abstract}
Berdasarkan permasalahan yang dipaparkan di atas, maka perlu dilakukan penelitian dengan melihat pengaruh penerapan suplemen buku siswa berbasis scientific approach terhadap hasil belajar dan sikap ilmiah siswa.
\end{abstract}

\section{METODE}

Teknik pengambilan sampel pada penelitian ini menggunakan teknik random sampling (sampel acak). Berdasarkan populasi yang terdiri dari 5 kelas diambil 2 kelas dengan undian, sehingga diperoleh kelas X IPA1 dengan jumlah 35 siswa sebagai kelas eksperimen dan kelas $\mathrm{X}$ IPA2 dengan jumlah 34 siswa sebagai kelas kontrol. Penelitian ini merupakan penelitian quasi eksperimen (eksperimen semu) karena peneliti tidak mungkin dapat mengendalikan semua variabel yang mungkin berpengaruh terhadap variabel yang diteliti. Penelitian dilakukan secara langsung dalam kegiatan pembelajaran pada siswa kelas $\mathrm{X}$ IPA SMA Negeri 15 Bandarlampung. Desain penelitian yang digunakan dalam penelitian ini adalah Pretest-Posttest Control Group Design.

Teknik pengumpulan data yang dilakukan dalam penelitian ini adalah dengan menggunakan metode pretest dan posttest siswa. Metode ini digunakan untuk mengetahui perbedaan hasil belajar dan sikap ilmiah antara kelas eksperimen dan kelas kontrol. Data yang diperoleh akan melalui uji normalitas, uji homogenitas, dan uji independent sampel t-test serta dihitung effect sizedari data yang diperoleh. Uji tersebut dilakukan untuk menguji hipotesis dari penelitian ini yaitu apakah terdapat pengaruh penerapan suplemen buku siswa berbasis scietific approach terhadap hasil belajar dan sikap ilmiah siswa.

\section{HASIL DAN PEMBAHASAN}

\section{Hasil}

Berdasarkan penelitian yang telah dilakukan di SMA Negeri 15 Bandarlampung pada semester genap tahun ajaran 2018/2019 diperoleh data hasil penelitian yang terdiri dari data pretest, posttest, dan N-Gain dari dua kelas, yaitu kelas eksperimen dan kelas kontrol. Pretest ini dilakukan 
Kurniawan., Suyanto., Nyeneng. - Pengaruh Penerapan Suplemen Buku...

untuk mengukur kemampuan awal siswa berupa aspek kognitif dan sikap ilmiah pada materi dinamika gerak. Posttest yang bertujuan untuk mengukur sejauh mana peningkatan hasil belajar kognitif dan sikap ilmiah siswa, dilaksanakan setelah dua kelas melaksanakan proses pembelajaran dengan perlakuan yang berbeda. $N$ gain dihitung untuk menunjukkan rata-rata perbedaan kedua kelas, di mana kelas eksperimen dalam pembelajaran dilengkapi dengan suplemen buku siswa berbasis sceintific approach sementara kelas kontrol hanya menggunakan buku teks. Berbagai uji dengan bantuan program SPSS 20 dilakukan setelah semua data diperoleh.

Berdasarkan pengujian untuk mengetahui kemampuan awal hasil belajar kelompok eksperimen dan kelompok kontrol dengan menggunakan uji independent sampel t-test menunjukkan bahwa tidak terdapat perbedaan signifikan ratarata hasil belajar (prestest) antara kelas ekperimen dan kelas kontrol. Hal tersebut terlihat dari hasil uji yang menunjukkan nilai $t_{\text {hitung }}<\mathrm{t}_{\text {tabel }}$ $(1,187<1,996)$ dan nilai sig. $(2-$ tailed) $0,239>0,05$ pada taraf signifikansi $95 \%$. Sementara itu, hal yang sama terjadi pada sikap ilmiah siswa. Tidak terdapat perbedaan signifikan rata-rata sikap ilmiah (prestest) antara kelas ekperimen dan kelas kontrol. Hal tersebut terlihat dari hasil uji yang menunjukkan nilai $\mathrm{t}_{\text {hitung }}<\mathrm{t}_{\text {tabel }}(-331<1,996)$ dan nilai sig. (2-tailed) $0,742>0,05$ pada taraf signifikansi $95 \%$. Sehingga kelas eksperimen dan kelas kontrol dapat dikatakan memiliki kemampuan awal yang sama, baik dari hasil belajar maupun sikap ilmiah siswa.

Adapun setelah dilakukan pembelajaran dengan menggunakan tambahan suplemen buku siswa berbasis scientific approach pada kelas eksperimen dan hanya buku teks pada kelas kontrol diperoleh ratarata-rata hasil belajar kelas eksperimen lebih tinggi dibandingkan kelas kontrol $(83,62>74,41)$ begitu juga pada sikap ilmiah $(4,03>3,90)$. Hasil uji independet sampel t-test $N$ gainvariabel hasil belajar, menunjukkan nilai $t_{\text {hitung }}>t_{\text {tabel }}$ $(3,629>1,996)$ dan nilai sig. (2tailed) $\quad 0,001>0,05$ pada taraf signifikansi $95 \%$. Sementara itu pada 
Kurniawan., Suyanto., Nyeneng. - Pengaruh Penerapan Suplemen Buku...

variabel sikap ilmiah menunjukkan nilai $t_{\text {hitung }}>t_{\text {tabel }}(5,564>1,996)$ dan nilai sig. (2-tailed) 0,000>0,05 pada taraf signifikansi $95 \%$.Hal tersebut menunjukkan bahwa ada perbedaan signifikan antara kelas eksperimen dan kelas kontrol, yang berarti ada pengaruh penggunaan suplemen buku siswa berbasis scientific approach terhadap hasil belajar dan sikap ilmiah.

Adanya pengaruh penggunaan suplemen buku siswa berbasis scientific approach terhadap hasil belajar diperkuat dengan hasil $N$-gain yang juga menunjukkan adanya perbedaan dari kedua kelas. $N$-gain hasil belajar kelas eksperimen lebih tinggi dibandingkan kelas kontrol $(0,75>0,62)$, di mana $N$-gain kelas ekperimen berkriteria tinggi dan kelas kontrol berkriteria sedang. Pada sikap ilmiah hasil $N$-gain yang juga menunjukkan adanya perbedaan dari kedua kelas. $N$-gain sikap ilmiah kelas eksperimen lebih tinggi dibandingkan kelas kontrol (0,32 > 0,23), di mana $N$-gain kelas ekperimen berkriteria sedang dan kelas kontrol berkriteria rendah. Hal itu menunjukkan bahwa dengan pembelajaran menggunakan suplemen buku siswa berbasis scientific approach meningkatkan hasil belajar kognitif dan sikap ilmiah. Hasil perhitungan effect size juga memperlihatkan bahwa penerapan suplemen buku siswa berbasis scientific approach memiliki interpretasi pengaruh yang besar terhadap hasil belajar dan sikap ilmiah.

Penerapan pembelajaran dengan scientific approach menghasilkan peningkatan pada hasil belajar dan sikap ilmiah. Hal tersebut bersesuaian dengan penelitian yang dilakukan Afriani (2017) bahwa terdapat pengaruh scientific approach terhadap peningkatan hasil belajar siswa. Selain itu penelitian yang dilakukan Aulia, Fadiawati, dan Tania (2017), yang menyatakan bahwa pembelajaran menggunakan scientific approach efektif dalam meningkatkan pemahaman konseptual dan sikap ilmiah siswa. Namun dalam penelitian ini kelas eksperimen memiliki peningkatan hasil belajar dan sikap ilmiah yang lebih tinggi dibandingkan kelas kontrol. Hal itu karena, pada kelas eksperimen 
menggunakan tambahan suplemen buku siswa berbasis scientific approach .

$$
\text { Buku teks pelajaran sebagai }
$$
bahan ajar yang diterbitkan pemerintah menjabarkan usaha minimal yang harus dilakukan guru dan siswa untuk mencapai kompetensi yang diharapkan, namun diperlukan penyesuaian karakteristik siswa (Widiana, 2014). Kondisi ini juga berawal dari kesan pertama yang buruk dengan buku, dalam hal ini buku teks pelajaran yang angker, berat, dan kurang menarik (Sandi, Setiawan, \& Rusnayati, 2014).

Penggunaan suplemen buku siswa berbasis scientific approach dalam proses pembelajaran membuat siswa lebih termotivasi berinteraksi dengan suplemen buku siswa dikarenakan terdapat stimulusstimulus yang membangkitkan minat baca siswa pada suplemen buku siswa berbasis scientific approach. Sementara itu pada kelas kontrol yang hanya menggunakan buku teks pelajaran, respon yang diberikan siswa terhadap buku teks pelajaran cenderung pasif dalam arti jarang sekali siswa melakukan interaksi dengan buku teks pelajaran, selain jika diperintah oleh guru. Penelitian Rizki, Irwandi, dan Bahriar (2016) menyatakan bahwa bahan pembelajaran yang digunakan dalam suplemen buku siswa yang dibuat harus lebih aplikatif, jadi dapat untuk meningkatkan minat baca siswa, karena tidak hanya sekedar konsep yang mereka dapatkan tapi kegunaan untuk kehidupannya juga.

Pembelajaran yang dilengkapi dengan menggunakan suplemen buku siswa berbasis scientific approach mendorong siswa melakukan dengan maksimal aspek psikomotorya berupa: kegiatan pengamatan, bekerja sesuai prosedur, membuat kesimpulan dan mengkomunikasikan pengalaman belajarnya baik berupa pengetahuan sebelumnya maupun pengetahuan yang diperoleh selama mengikuti pembelajaran. Pada saat melakukan diskusi kelompok, kerjasama siswa lebih terlihat. Sementara itu pada kelas yang tidak dilengkapi degan suplemen buku siswa berbasis scientific approach terkadang siswa bingung dengan apa yang mereka perbuat dalam aktivitas mengamati, dalam bekerja masih belum mengikuti 
langkah-langkah yang benar, belum mampu membuat kesimpulan berdasarkan pemahaman dan bahasa sendiri, dan belum dapat mengomunikasikan penegetahuannya baik dalam bentuk prtanyaan yang diajukan oleh guru, maupun kelompok yang lain. Hal ini sejalan dengan pernyataan Fauziah, Abdullah, dan Hakim (2013) bahwa tahap-tahap scientific approach dapat meningkatkan kempuan siswa dalam mengamati, menanya, mencoba, mengasosiasi, membuat jejaring dan menarik kesimpulan serta mengkomunikasikan temuannya sehingga berdampak positif terhadap soft skill-nya.

Penggunaan suplemen buku siswa berbasis scientific approach dalam proses pembelajaran siswa menjadi lebih lebih aktif dan dapat mengkonstruk sendiri pengetahuan dengan melibatkan secara maksimal seluruh kemampuan siswa untuk menyelidiki secara sistematis, kritis, logis dan analitis. Selain itu penggunaan suplemen buku siswa berbasis scientific approach pada materi dinamika gerakdapat membantu guru menyampaikan materi yang cakupannya lebih banyak dengan baik. Salah satunya ialah materi Hukum II Newton yang sangat terlihat perbedaan reaksi siswa terhadap suplemen buku siswa antara kelas eksperimen dan kelas kontrol.

Untuk menemukan persamaan Hukum Newton II dilakukan sebuah percobaan. Percobaan Hukum II Newton yang ada pada suplemen buku siswa, di mana siswa menggunakan alat percobaan yang terkesan baru bagi mereka, salah satunya ialah ticker timer. Pada langkah percobaan yang dilakukan, selalu melibatkan aspek psikomotorik siswa, seperti halnya merangkai alat, menggunting dan menempel hasil percobaan. Hal tersebut membuat siswa menjadi lebih mampu bekerja keras, bertanggung jawab, dan memiliki rasa keingintahuan yang tinggi. Terkonstruknya suplemen buku siswa mulai dari skema percobaan, langkah percobaan, hingga pembahasan percobaan membuat siswa lebih banyak memiliki kesempatan memperoleh pemahamannya secara langsung dari hasil pemikirannya dan diskusi yang dilakukan dan tidak membuat siswa 
Kurniawan., Suyanto., Nyeneng. - Pengaruh Penerapan Suplemen Buku...

mengalami kebingungan dengn langkah-langkah yang akan mereka lakukan. Pada percobaan Hukum II Newton yang ada pada suplemen buku siswa ini juga, siswa mampu menemukan persamaan Hukum II Newton melalui pengalamannya sendiri sehingga membuat pembelajaran yang telah dilalui menjadi berkesan.

Perbedaan perilaku siswa antara kelas yang dilengkapi dengan suplemen buku siswa berbasis scientific approach (kelas ekperimen) dan kelas yang hanya menggunakan buku teks (kelas kontrol) seperti dipaparkan di atas, berpengaruh terhadap sikap ilmiah siswa. Terlihat bahwa pada kelas eksperimen siswa lebih aktif, rasa ingin tahunya tinggi, sikap kritis terhadap satu permasalahan juga tinggi dan sikapsikap lain yang menandakan perbedaan sikap ilmiah siswa. Hal ini sejalan dengan penelitian yang dilakukan Ratnasari (2017) di mana terdapat hubungan antara scientific approach terhadap sikap ilmiah siswa. Besarnya pengaru scientific approach terhadap sikap ilmiah siswa sebsar $60,1 \%$.
Berdasarkan perbedaan perilaku siswa yang dipaparkan, tentunya juga berpengaruh terhadap hasil belajar sisiwa. Hasil penelitian ini sejalan dengan hasil dari penelitian tentang penggunaan suplemen dalam pembelajaran, diantaranya penelitian yang dilakukan oleh Riswakhyuningsih (2015) yang menyatakan bahwa suplemen bahan ajar berpengaruh terhadap hasil belajar kognitif dan aktivitas belajar. Selain itu penelitian yang dilakukan Soleha (2017) menggunakan suplemen buku siswa menghasilkan efektivitas hingga 78,63\% terhadap kelulusan siswa.

Belajar pada hakikatnya adalah kegiatan yang dilakukan secara sadar untuk menghasilkan suatu perubahan yang menyangkut pengetahuan, keterampilan, sikap, dan nilai-nilai. Pada penelitian ini penggunaan suplemen buku siswa berbasis scientific approach menuntut siswa untuk belajar mandiri. Dengan suplemen buku siswa berbasis scientific approach siswa mampu berfikir secara ilmiah dan menemukan sendiri konsep yang mereka pelajari. Sehingga terjadi 


\section{Kurniawan., Suyanto., Nyeneng. - Pengaruh Penerapan Suplemen Buku...}

perubahan pada diri siswa tersebut baik dari segi pengetahuan, keterampilan, sikap, dan nilai ilmiah.

Berdasarkan uraian di atas dengan pembelajaran menggunakan suplemen buku siswa berbasis scientific approach memberikan pengaruh yang signifikan terhadap hasil belajar yang dicapai oleh siswa sehingga hasil belajar siswa meningkat. Selain itu, penggunaan suplemen buku siswa scientific approach dalam proses pembelajaran dapat menumbuhkan sikap ilmiah, sehingga pembelajaran menjadi lebih bermakna dan siswa dapat menemukan sendiri pengetahuannya.

\section{KESIMPULAN DAN SARAN}

\section{Kesimpulan}

Berdasarkan hasil penelitian dan pembahasan dapat disimpulkan bahwaterdapat pengaruh penerapan suplemen buku siswa berbasis scientific approach terhadap hasil belajar siswa. Hal itu terlihat dari nilai $t_{\text {hitung }}>t_{\text {tabel }}(3,608>1,996)$ dan nilai sig. (2-tailed)0,001<0,05 pada taraf signifikansi $95 \%$ yang berarti ada perbedaan signifikan antara pembelajaran yang dilengkapi suplemen buku siswa berbasis scientific approach dan pembelajaran yang tidak dilengkapi suplemen buku siswa berbasis scientific approach .

Terdapat pegaruh penerapan suplemen buku siswa berbasis scientific approach terhadap sikap ilmiah siswa. Hal itu terlihat dari nilai $t_{\text {hitung }}>t_{\text {tabel }}(5,564>1,996)$ dan nilai sig. (2-tailed) $0,000<0,05$ pada taraf signifikansi 95\%. yang berarti ada perbedaan signifikan antara pembelajaran yang dilengkapi suplemen buku siswa berbasis scientific approach dan pembelajaran yang tidak dilengkapi suplemen buku siswa berbasis scientific approach .

\section{Saran}

Berdasarkan hasil penelitian yang telah dilakukan, peneliti memberi saran Guru sebaiknya menggunakan tambahan suplemen buku berbasis scientific approach untuk meningkatkan hasil belajar dan sikap ilmiah siswa yang lebih tinggi

Kekurangan dalam penelitian ini terdapat pada pengukuran hasil belajar yang hanya terdapat pada ranah kognitif saja, sedangkan seharusnya untuk pembelajaran 
Kurniawan., Suyanto., Nyeneng. - Pengaruh Penerapan Suplemen Buku...

scientific approach jugaterdapat ranah afektif dan psikomotor. Peneliti selanjutnya diharapkan mampu mengukur hasil belajar afektif dan psikomotor sehingga di dapatkan hasil belajar yang diinginkan.

\section{DAFTAR PUSTAKA}

Afriani, W. 2017. Pengaruh Pendekatan Saintifik Terhadap Peningkatan Hasil Belajar Kelas X di SMAN 1 Waway Karya. Jurnal Ilmiah Pendidikan Fisika Al-Biruni. 4 (2) : 82-92.

Aulia, N. P., Fadiawati, N., Tania L. 2017. Efektivitas Pendekatan Saintifik dalam Meningkatkan Pemahaman Konseptual pada Materi Pemisahan Campuran. Jurnal Pendidikan dan Pembelajaran Kimia. 6 (1) : 130-144.

Bancong, H., \& Song, J. (2018). Do Physics Textbooks Present the Ideas of Thought Experiments ?: a Case in Indonesia. Jurnal Pendidikan IPA Indonesia. 7(1), 25-33.

Fauziah, R., Abdullah, A. G., dan Hakim, D. L. 2013. Pembelajaran Scientific Elektronika Dasar Berorientasi Pembelajaran Berbasis Masalah. Jurnal Invotec. 9 (2) : 165-178

Ratnasari, E. 2017. Pengaruh Pendekatan Saintifik Terhadap Sikap Ilmiah Dalam Pembelajaran Sejarah Kelas XI IPS 1 di SMA Ma'Arif
Sukorejo. e-Jurnal Pendidkan Sejarah. 5 (1) : 1-14.

Rizki, M., Irwandi D., \& Bahriar E. S. 2016. Pengembangan Buku Suplemen Siswa Berbasis Sains Teknologi Masyaratkat pada Materi Kimia Polimer. Jurnal Tadri Kimiya. 1 (2) :47-57.

Sandi, M.I., Setiawan, A., \& Rusnayati, H. 2014. Analisis Buku Ajar Fisika SMA Kelas X di Kota Bandung Berdasarkan Komponen Literasi Sains. Prosiding Seminar Nasional Fisika (E-Journal). 3 (2014) : 94-102.

Soleha, S. 2017. Pengembangan Buku Suplemen Siswa berbasis Multi Representasi pada Materi Hukum II Newton. Jurnal Pembelajaran Fisika Universitas Lampung. 5 (4) : 31-40.

Supardi, A. 2014. Penggunaan Multimedia Interaktif Sebagai Bahan Ajar Suplemen Dalam Peningkatan Minat Belajar. Jurnal Ilmiah Pendidikan Dasar. 1 (2) : 161-167.

Widiana, G. T., dan Wardani, I. K. 2017. Efektifitas Suplemen Bahan Ajar IPA dengan Pendekatan Saintifik untuk Siswa Kelas IV SD. Jurnal Pendidikan Dasar Nusantara. 3 (1) : 41-55. 